\title{
Prevalence of Human Immunodeficiency Virus (HIV) and chronic Hepatitis C Virus (HCV) coinfection in people treated at a Referral Service in Southern Brazil
}

\author{
Prevalência da coinfecção pelo Vírus da Imunodeficiência Humana (HIV) e Vírus da Hepatite C \\ crônica (HCV) em pessoas atendidas em um Serviço de Referência no Sul do Brasil \\ Prevalencia de coinfección por el Virus de la Inmunodeficiencia Humana (HIV) y el Virus de la \\ Hepatitis C crónica (VHC) en personas atendidas en un Servicio de Referencia en el Sur de Brasil
}

Received: 02/01/2022 | Reviewed: 02/09/2022 | Accept: 02/13/2022 | Published: 02/19/2022

\author{
Mariane D'Avila Vecchi \\ ORCID: https://orcid.org/0000-0002-2097-7535 \\ Universidade Federal de Pelotas, Brazil \\ E-mail: mariane.vecchi@ufpel.edu.br \\ Marysabel Pinto Telis Silveira \\ ORCID: https://orcid.org/0000-0002-6453-8534 \\ Universidade Federal de Pelotas, Brazil \\ E-mail: marysabelfarmacologia@gmail.com \\ Geraldo Ustárroz da Silva Tavares \\ ORCID: https://orcid.org/0000-0002-9684-6451 \\ Universidade Federal de Pelotas, Brazil \\ E-mail: geraldotavares650@ hotmail.com \\ Matheus Winck Willers \\ ORCID: https://orcid.org/0000-0001-8349-6280 \\ Universidade Federal de Pelotas, Brazil \\ E-mail: matheus.willers@hotmail.com \\ Stefanie Bressan Waller \\ ORCID: https://orcid.org/0000-0001-6719-1794 \\ Universidade Federal de Pelotas, Brazil \\ E-mail: waller.stefanie@yahoo.com.br \\ Daniela Isabel Brayer Pereira \\ ORCID: https://orcid.org/0000-0003-4374-677X \\ Universidade Federal de Pelotas, Brazil \\ E-mail: danielabrayer@gmail.com
}

\begin{abstract}
This study aimed to evaluate the prevalence of HIV/HCV coinfection and associated factors in people living with HIV/AIDS enrolled in a Specialized Care Service in Southern Brazil (Pelotas, RS). For methodology, a descriptive retrospective outpatient study was carried out with 1,017 people living with HIV/AIDS, aged 18 years or older, enrolled in the SAE between 2009 and 2014. The analyzed characteristics were divided into three levels: sociodemographic (gender, skin color, age, schooling in years of study), behavioral (home arrangement, smoking status, alcohol use, illicit drug use and injectable drug use, blood transfusion, heterosexual and homosexual contact) and clinical (diabetes, dyslipidemia, hepatic steatosis, hepatitis B, obesity, first CD4 count and lowest CD4 count). The results showed a prevalence of HIV/HCV coinfection in the assessed individuals in 8.3\% (84/1,017). Women living with HIV had a $35 \%$ lower prevalence of HIV/HCV coinfection than men living with HIV. Injectable drug use $(32.4 \%)$ had more than twice the HIV/HCV coinfection rate. Moreover, patients with hepatitis B (25\%) had a sixfold higher prevalence rate of HIV/HCV coinfection. We concluded that male individuals, injectable drug use, and patients with hepatitis B are more likely to have HIV/HCV coinfection. It is important to implement comprehensive strategies for preventing, diagnosing, and treating viral hepatitis in people living with HIV/AIDS.
\end{abstract}

Keywords: HIV/AIDS; Hepatitis C; Hepatitis B; Coinfection; Intravenous drugs.

\section{Resumo}

O objetivo deste estudo foi avaliar a prevalência da coinfecção HIV/HCV e fatores associados em pessoas vivendo com HIV/AIDS cadastradas em um Serviço de Atenção Especializada do Sul do Brazil (Pelotas, RS). Como metodologia, foi realizado um estudo ambulatorial retrospectivo descritivo com 1.017 pessoas vivendo com HIV/AIDS, com idade igual ou superior a 18 anos, cadastradas na SAE entre 2009 e 2014. As características analisadas foram divididas em três níveis: sociodemográficos (sexo, cor da pele, idade, escolaridade em anos de estudo), comportamentais (arranjo domiciliar, tabagismo, uso de álcool, uso de drogas ilícitas e injetáveis, hemotransfusão, contato heterossexual e homossexual) e clínico (diabetes, dislipidemia, esteatose hepática, hepatite B, 
obesidade, primeira contagem de CD4 e contagem mais baixa de CD4). Os resultados mostraram uma prevalência de coinfecção HIV/HCV nos indivíduos avaliados em 8,3\% (84/1.017). As mulheres vivendo com HIV tiveram uma prevalência 35\% menor de coinfecção HIV/HCV do que os homens vivendo com HIV. O uso de drogas injetáveis $(32,4 \%)$ apresentou mais que o dobro da taxa de coinfecção HIV/HCV. Além disso, pacientes com hepatite B (25\%) apresentaram prevalência seis vezes maior de coinfecção HIV/HCV. Concluímos que indivíduos do sexo masculino, usuários de drogas injetáveis e portadores de hepatite B são mais propensos à coinfecção HIV/HCV. É importante implementar estratégias abrangentes de prevenção, diagnóstico e tratamento das hepatites virais em pessoas vivendo com HIV/AIDS.

Palavras-chave: HIV/AIDS; Hepatite C; Hepatite B; Coinfecção; Drogas intravenosas.

\section{Resumen}

El objetivo de este estudio fue evaluar la prevalencia de la coinfección por el virus de la inmunodeficiencia humana (VIH) / virus de la hepatitis C (VHC) y los factores asociados en personas que viven con el VIH/SIDA (Síndrome de Inmunodeficiencia Adquirida) inscritas en un Servicio de Atención Especializada en el Sur de Brazil (Pelotas, RS). Para la metodología, se realizó un estudio ambulatorio retrospectivo descriptivo con 1.017 personas viviendo con VIH/SIDA, con edad igual o superior a 18 años, inscritas en el SAE entre 2009 y 2014. Las características analizadas se dividieron en tres niveles: sociodemográfico (género, color de piel, edad, escolaridad en años de estudio), conductual (arreglo del hogar, tabaquismo, consumo de alcohol, consumo de drogas ilícitas y de inyectables, transfusión de sangre, contacto heterosexual y homosexual) y clínico (diabetes, dislipidemia, esteatosis hepática, hepatitis $\mathrm{B}$, obesidad, primer recuento de CD4 y recuento de CD4 más bajo). Los resultados mostraron una prevalencia de coinfección VIH/VHC en los evaluados del 8,3\% (84/1.017). Las mujeres que viven con el VIH tenían una prevalencia de coinfección por $\mathrm{VIH} / \mathrm{VHC}$ un $35 \%$ menor que los hombres que vivían con el VIH. El uso de drogas inyectables $(32,4 \%)$ tuvo más del doble de la tasa de coinfección por VIH/VHC. Además, los pacientes con hepatitis B (25\%) tenían una tasa de prevalencia seis veces mayor de coinfección por VIH/VHC. Concluimos que los hombres, los usuarios de drogas inyectables y los pacientes con hepatitis B tienen más probabilidades de tener una coinfección por el VIH/VHC. Es importante implementar estrategias integrales para la prevención, diagnóstico y tratamiento de las hepatitis virales en personas que viven con VIH/SIDA.

Palabras clave: HIV/AIDS; Hepatitis C; Hepatitis B; Coinfección; Medicamentos intravenosos.

\section{Introduction}

The identification of the acquired immunodeficiency syndrome (AIDS) marked the beginning of the 1980s, and in 1984, had its causative agent isolated and characterized as a virus belonging to the Retroviridae family. This virus was then called the Human Immunodeficiency Virus - HIV (Gallo \& Montagnier, 2003). AIDS is currently an epidemic disease that affects the overall population, regardless of gender or sex (Le Loup et al., 2009). According to Joint United Nations Program on HIV/AIDS, 37.7 million people worldwide were living with HIV until 2020 (UNAIDS, 2021). In Brazil, 381,793 cases of people living with HIV were reported from 2007 to June 2021 (Brazil, 2021). Antiretroviral therapy is the treatment that increases survival and decreases mortality in people living with HIV/AIDS (Mugisha et al., 2016). However, this treatment can suffer the interference of several factors associated with HIV, such as opportunistic infections, comorbidities, and coinfections (Mirzaei et al., 2013).

The HIV and hepatitis C virus (HIV/HCV) coinfection is an important public health problem, sharing similar routes of transmission among affected populations (Tengan et al., 2016). It is estimated that 2.3 million people worldwide live with this coinfection (Platt et al., 2016). HIV/HCV coinfection has an impact on HCV viremia, accelerating the progression of chronic liver disease and increasing mortality (Focà et al., 2016; Rosenthal et al., 2015). Moreover, HCV infection can cause a decrease in T cells, accelerating the progression of HIV (Rallón et al., 2017). In a retrospective longitudinal study carried out in the state of Paraná, Brazil, from 2002 to 2016, with 3,340 people living with HIV/AIDS, it was observed that individuals with HIV/HCV coinfection had lower CD4 cell counts than HIV/AIDS mono-infected individuals, even during antiretroviral therapy follow-up (Silva et al., 2018).

Since antiretroviral therapy was introduced for the treatment of HIV/AIDS, complications related to HCV, especially end-stage liver disease and hepatocellular carcinoma, have become the leading causes of death in people living with HIV/AIDS (Rosenthal et al., 2015). On the other hand, with the emergence of direct-acting antiviral agents (DAAs) for the 
treatment of hepatitis $\mathrm{C}$, there has been a significant reduction in complications associated with liver disease and extrahepatic dysfunction, improving the clinical outcomes and survival of these patients (Bruno et al., 2017). The effectiveness of the treatment with DAAs seems to be similar in HIV/HCV coinfected patients and HCV mono-infected patients (Zheng, Ma, Xiong, \& Fan, 2020). Regular antiretroviral therapy follow-up may favor the response to treatment with DAAs in coinfected patients (Peters et al., 2018).

The importance of treating individuals for HCV is highlighted, due to the high rates of morbidity, mortality, and complications associated with HIV/HCV coinfection (Palella \& Phair, 2011; Zayedi t al., 2020). It is necessary to improve the prevention, diagnosis, and surveillance at the global level of HCV prevalence in different population groups (Platt et al., 2016). The World Health Organization's global goals are to reduce new viral hepatitis infections by $90 \%$ and reduce deaths from viral hepatitis by 65\% up to 2030 (WHO, 2016). Moreover, there are few studies related to hepatitis C in Brazil (Carvalho et al., 2020) and, given this situation, considered important to know the prevalence of this infection.

This study aimed to evaluate the prevalence of HIV/HCV coinfection and associated factors in people living with HIV/AIDS enrolled in a Specialized Care Service in Southern Brazil (Pelotas, RS).

\section{Methodology}

\subsection{Research}

This work is a transversal and observational study from a quantitative approach (Pereira et al., 2018) to assess the prevalence of HIV/HCV coinfection and associated factors in people living with HIV/AIDS

\subsection{Ethical permission}

The study was approved by the Ethics Committee for Research with Human Subjects of Federal University of Pelotas (CAAE: 34942720.7.0000.5317) The present work was carried out with full confidentiality of information.

\subsection{Study design}

A retrospective descriptive study was carried out with data from medical records obtained at a Specialized Care Service at the Outpatient Clinic of the Faculty of Medicine, Federal University of Pelotas (SCS-UFPEL, Pelotas, RS, Southern Brazil).

\subsection{Patient selection and clinic parameters}

A total of 1,017 medical records of people living with HIV/AIDS aged 18 years or older, who had their first appointment during the period from 2009 to 2014 at the SCS-UFPEL, were analyzed.

The following information was extracted from the medical records: sex/gender, age (continuous), skin color (white, brown, yellow, black), schooling in years of study (continuous in full years), home arrangement (lives alone, with partner/friend, with other family members), smoking status and alcohol use or illicit drug, forms of transmission (injectable drug use, blood transfusion, heterosexual and homosexual contact). Additionally, first CD4 count, lowest CD4 count, antiretroviral treatment, hepatitis $\mathrm{C}$, hepatitis B, diabetes, dyslipidemia, obesity, and hepatic steatosis were also analyzed.

\subsection{Statistical analysis}

The collected data were transcribed to an Excel spreadsheet and checked, with $20 \%$ of the data being submitted to quality control. Subsequently, the data were transferred to a database using the Stata 12 statistical package (StataCorp LP, College Station, USA). Initially, a descriptive analysis of the sample was performed between the different categories of the 
studied variables, with their respective 95\% confidence intervals and stratified for HCV coinfection. To assess the statistical difference between the variables, Pearson's Chi-square test was performed, using Pearson's exact test when necessary, and the linear trend test was used for ordinal categorical variables, with values of $p<0.05$ being considered statistically significant.

To verify the association between the outcome and the independent variables, the crude and adjusted analyses were conducted using Poisson regression with robust variance, at three levels. The first level included the sociodemographic variables (sex/gender, skin color, age, and schooling in years of study), whereas the second level included the behavioral variables (home arrangement, smoking status, alcohol use, illicit drug use, injectable drug use, blood transfusion, heterosexual and homosexual contact) and the third level the clinical variables (diabetes, dyslipidemia, hepatic steatosis, hepatitis B, obesity, first CD4 count and lowest CD4 count). Variables with $p<0.2$ in the crude analysis were included in the multivariate analysis.

\section{Results}

Between January 2009 and December 2014, a total of 1,017 medical records from SCS-UFPEL was analyzed, revealing that all patients $(100 \%)$ living with HIV/AIDS included in this study used antiretroviral therapy.

Of the assessed patients (Table 1), 55.5\% were male, white (68.8\%), aged between 31 and 50 years old, with 5 to 8 years of schooling, living with family members $(43.6 \%)$, and were smokers $(66.8 \%)$. In $35.8 \%$ of the patients, the first CD4 count was $>500$ cells $/ \mathrm{mm}^{3}$ and in $39.2 \%$ of them, the lowest CD4 count was $\leq 200$ cells $/ \mathrm{mm}^{3}$. Of the total number of patients, $84(8.3 \%)$ had a diagnosis of hepatitis C (HIV/HCV coinfection), and of these, $26.2 \%$ underwent treatment with DAAs and $76.3 \%$ attained sustained virologic response (data not shown in table).

Table 1 - Sociodemographic and health characteristics of people living with HIV/AIDS in Southern Brazil, between January 2009 and December 2014, and their correlation with hepatitis C virus (HCV) co-infection.

\begin{tabular}{|c|c|c|c|c|}
\hline \multirow[b]{2}{*}{ Variable } & \multirow{2}{*}{$\begin{array}{c}\text { Patients with HIV } \\
n(\%)\end{array}$} & \multicolumn{3}{|c|}{ HIV/HCV coinfection } \\
\hline & & $\begin{array}{c}\text { Yes } \\
n(\%)\end{array}$ & $\begin{array}{c}\text { No } \\
n(\%)\end{array}$ & $p$-value \\
\hline \multicolumn{5}{|l|}{ Gender } \\
\hline Male & $564(55.5)$ & $56(9.9)$ & $508(90.1)$ & \multirow{2}{*}{$0.031^{\dagger}$} \\
\hline Female & $453(44.5)$ & $28(6.2)$ & $425(93.8)$ & \\
\hline \multicolumn{5}{|l|}{ Skin color } \\
\hline White & $592(68.8)$ & $48(8.1)$ & $544(91.9)$ & \multirow{3}{*}{$0.831^{\dagger}$} \\
\hline Black & $201(23.4)$ & $19(9.5)$ & $182(90.5)$ & \\
\hline Brown/Yellow & $67(7.8)$ & $6(9.0)$ & $61(91.0)$ & \\
\hline \multicolumn{5}{|l|}{ Age (years) } \\
\hline $22-30$ & $130(12.8)$ & $3(2.3)$ & $127(97.7)$ & \multirow{5}{*}{$0.001^{*}$} \\
\hline $31-40$ & $284(27.9)$ & $19(6.7)$ & $265(93.3)$ & \\
\hline $41-50$ & $271(26.7)$ & $21(7.7)$ & $250(92.3)$ & \\
\hline $51-60$ & $197(19.4)$ & $27(13.7)$ & $170(86.3)$ & \\
\hline$\geq 61$ & $134(13.2)$ & $14(10.4)$ & $120(89.6)$ & \\
\hline \multicolumn{5}{|l|}{ Schooling of study (years) } \\
\hline $0-4$ & $74(21.0)$ & $6(8.1)$ & $68(91.9)$ & \multirow{4}{*}{$0.035^{*}$} \\
\hline $5-8$ & $139(39.5)$ & $12(8.6)$ & $127(91.4)$ & \\
\hline $9-11$ & $80(22.7)$ & $3(3.7)$ & $77(96.3)$ & \\
\hline$\geq 12$ & $59(16.8)$ & $1(1.7)$ & $58(98.3)$ & \\
\hline \multicolumn{5}{|l|}{ Home arrangement } \\
\hline Living alone & $224(29.2)$ & $25(11.2)$ & $199(88.8)$ & \multirow{3}{*}{$0.252^{\dagger}$} \\
\hline Living with partner/friend & $208(27.2)$ & $19(9.1)$ & $189(90.9)$ & \\
\hline Living with family members & $334(43.6)$ & $22(6.6)$ & $312(93.4)$ & \\
\hline \multicolumn{5}{|l|}{ Smoking status } \\
\hline Yes & $530(66.8)$ & $61(11.5)$ & $469(88.5)$ & \multirow{2}{*}{$0.009^{\dagger}$} \\
\hline \multirow{2}{*}{\multicolumn{5}{|c|}{ Alcohol use }} \\
\hline & & & & \\
\hline Yes & $319(47.5)$ & $42(13.2)$ & $277(86.8)$ & \multirow{3}{*}{$0.002^{\dagger}$} \\
\hline No & $352(52.5)$ & $22(6.3)$ & $330(93.7)$ & \\
\hline Illicit drug use & & & & \\
\hline
\end{tabular}




\begin{tabular}{|c|c|c|c|c|}
\hline Yes & $251(38.9)$ & 44 (17.5) & $207(82.5)$ & \multirow{2}{*}{$<0.001^{\dagger}$} \\
\hline No & $394(61.1)$ & $22(5.6)$ & $372(94.4)$ & \\
\hline \multicolumn{5}{|l|}{ Injectable drug use } \\
\hline $\begin{array}{l}\text { Yes } \\
\text { No }\end{array}$ & $\begin{array}{c}68(12.0) \\
497(87.8)\end{array}$ & $\begin{array}{l}22(32.4) \\
29(5.8)\end{array}$ & $\begin{array}{l}46(67.6) \\
468(94.2)\end{array}$ & $<0.001^{\dagger}$ \\
\hline \multicolumn{5}{|l|}{ Blood Transfusion } \\
\hline $\begin{array}{l}\text { Yes } \\
\text { No }\end{array}$ & $\begin{array}{l}36(12.9) \\
243(87.1)\end{array}$ & $\begin{array}{l}4(11.1) \\
23(9.5)\end{array}$ & $\begin{array}{c}32(88.9) \\
220(90.5)\end{array}$ & $0.806^{\dagger}$ \\
\hline \multicolumn{5}{|l|}{ Heterosexual contact } \\
\hline $\begin{array}{l}\text { Yes } \\
\text { No }\end{array}$ & $\begin{array}{l}712(92.5) \\
58(7.5)\end{array}$ & $\begin{array}{l}58(8.2) \\
4(6.9)\end{array}$ & $\begin{array}{l}654(91.8) \\
54(93.1)\end{array}$ & $0.737^{\dagger}$ \\
\hline \multicolumn{5}{|l|}{ Homosexual contact } \\
\hline $\begin{array}{cc}\text { Yes } \\
\text { No }\end{array}$ & $\begin{array}{l}140(30.8) \\
315(69.2)\end{array}$ & $\begin{array}{l}14(10) \\
28(8.9)\end{array}$ & $\begin{array}{c}126(90) \\
287(91.1)\end{array}$ & $0.706^{\dagger}$ \\
\hline
\end{tabular}

$\dagger$ Pearson's chi-square test; + Linear trend test; some variables are not included in the total sample due to missing data in the medical records. Source: Authors.

Considering the HIV/HCV coinfected patients, it was observed that most were male $(p=0.031)$, with a linear trend between coinfection with age and schooling in years of study being observed. The proportion of HIV/HCV coinfection cases increased with age and decreased with the years of schooling. Smokers, alcohol use, illicit drug, and injectable drug also showed a higher proportion of coinfection. According to the clinical characteristics of people living with HIV/HCV coinfection, (Table 2), it was evidenced that diabetes $(p=0.022)$ and hepatitis $\mathrm{B}(p=0.001)$ were the clinical characteristics associated with the highest proportion of HIV/HCV coinfection. Other clinical conditions were also evidenced in people living with HIV/ HCV coinfection: dyslipidemia, obesity, hepatic steatosis, first CD4 count, and lowest CD4 count.

Table 2 - Clinical characteristics of people living with HIV/AIDS in Southern Brazil, between January 2009 and December 2014, and their correlation with hepatitis C virus (HCV) co-infection.

\begin{tabular}{|c|c|c|c|c|}
\hline \multirow[b]{2}{*}{ Variable } & \multirow[b]{2}{*}{$\begin{array}{c}\text { Patients with HIV } \\
n(\%)\end{array}$} & \multicolumn{3}{|c|}{ HIV/HCV coinfection } \\
\hline & & $\begin{array}{c}\text { Yes } \\
n(\%)\end{array}$ & $\begin{array}{c}\text { No } \\
n(\%)\end{array}$ & $p$-value \\
\hline \multicolumn{5}{|l|}{ Diabetes } \\
\hline Yes & $71(7.0)$ & $11(15.5)$ & $60(84.5)$ & \multirow{2}{*}{$0.022^{\dagger}$} \\
\hline No & $946(93.0)$ & $73(7.7)$ & $873(92.3)$ & \\
\hline \multicolumn{5}{|l|}{ Dyslipidemia } \\
\hline Yes & $119(11.7)$ & $8(6.7)$ & $111(93.3)$ & \multirow{2}{*}{$0.517^{\dagger}$} \\
\hline No & $898(88.3)$ & $76(8.5)$ & $822(91.5)$ & \\
\hline \multicolumn{5}{|c|}{ Hepatic Steatosis } \\
\hline Yes & $16(1.6)$ & $2(12.5)$ & $14(87.5)$ & \multirow[b]{2}{*}{$0.386^{\dagger}$} \\
\hline No & $1001(98.4)$ & $82(8.2)$ & $919(91.8)$ & \\
\hline \multicolumn{5}{|l|}{ Hepatitis B } \\
\hline Yes & $28(2.7)$ & $7(25)$ & $21(75)$ & \multirow[b]{2}{*}{$0.001^{\dagger}$} \\
\hline No & $989(97.3)$ & $77(7.8)$ & $912(92.2)$ & \\
\hline \multicolumn{5}{|l|}{ Obesity } \\
\hline Yes & $86(8.5)$ & $5(5.8)$ & $81(94.2)$ & \multirow{2}{*}{$0.538^{\dagger}$} \\
\hline No & $931(91.5)$ & $79(8.5)$ & $852(91.5)$ & \\
\hline \multicolumn{5}{|c|}{ First $\mathrm{CD} 4$ count $\left(\right.$ cells/mm $\left.{ }^{3}\right)$} \\
\hline$\leq 200$ & $283(27.9)$ & $19(6.7)$ & $264(93.3)$ & \multirow{4}{*}{$0.372^{\dagger}$} \\
\hline $201-350$ & $167(16.5)$ & $18(10.8)$ & $149(89.2)$ & \\
\hline $351-500$ & $202(19.9)$ & $12(5.9)$ & $190(94.1)$ & \\
\hline$>500$ & $363(35.8)$ & $35(9.6)$ & $328(90.4)$ & \\
\hline \multicolumn{5}{|c|}{ Lowest CD4 count $\left(\right.$ cells/mm $\left.{ }^{3}\right)$} \\
\hline$\leq 200$ & $398(39.2)$ & $29(7.3)$ & $369(92.7)$ & \multirow{4}{*}{$0.321^{*}$} \\
\hline $201-350$ & $266(26.2)$ & $26(9.8)$ & $240(90.2)$ & \\
\hline $351-500$ & $181(17.8)$ & $9(5.0)$ & $172(95.03)$ & \\
\hline$>500$ & $171(16.8)$ & $20(11.7)$ & $151(88.3)$ & \\
\hline
\end{tabular}

$\dagger$ Pearson's chi-square test; $\$$ Linear trend test; some variables are not included in the total sample due to missing data in the medical records. Source: Authors. 
Regarding the crude and adjusted analysis between the assessed variables and HIV/HCV coinfection (Table 3), a higher prevalence of coinfection was observed after 41 years of age. Women living with HIV had a $38 \%$ lower prevalence rate of hepatitis $\mathrm{C}$ coinfection than men. The prevalence of HIV/HCV coinfection was twice higher in smokers and alcohol use, more than threefold higher in illicit drug use, and fivefold higher in injectable drug use. Additionally, patients with diabetes had a twice higher rate of HIV/HCV coinfection, and patients with hepatitis B had a threefold higher rate.

Table 3 - Crude and adjusted analysis of sociodemographic, health and clinical characteristics of people living with HIV/AIDS and hepatitis C virus (HCV) co-infection in Southern Brazil, between January 2009 and December 2014.

\begin{tabular}{|c|c|c|c|c|}
\hline \multirow{2}{*}{ Variable } & \multirow{2}{*}{$\begin{array}{c}\text { Patients with HIV: } \\
n(\%)\end{array}$} & \multirow{2}{*}{$\begin{array}{c}\text { HIV/HCV } \\
\text { coinfection: } \\
n(\%) \\
\end{array}$} & \multicolumn{2}{|c|}{ 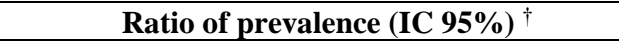 } \\
\hline & & & Crude & Adjusted \\
\hline \multicolumn{5}{|c|}{$\begin{array}{l}\text { Sociodemographic and health characteristics: } \\
\text { Gender }\end{array}$} \\
\hline $\begin{array}{l}\text { Gender } \quad \text { Male }\end{array}$ & $564(55.5)$ & $56(9.9)$ & 1 & 1 \\
\hline Female & $453(44.5)$ & $28(6.2)$ & $0.62(0.40-0.96)$ & $0.65(0.42-0.99)$ \\
\hline \multicolumn{5}{|l|}{ Skin color } \\
\hline White & $592(68.8)$ & $48(8.1)$ & 1 & \\
\hline Black & $201(23.4)$ & $19(9.5)$ & $1.17(0.70-1.94)$ & \\
\hline Brown/Yellow & $67(7.8)$ & $6(9.0)$ & $1.10(0.49-2.48)$ & \\
\hline \multicolumn{5}{|l|}{ Age (years) } \\
\hline $22-30$ & $130(12.8)$ & $3(2.3)$ & 1 & 1 \\
\hline $31-40$ & $284(27.9)$ & $19(6.7)$ & $2.90(0.87-9.63)$ & $2.79(0.84-9.27)$ \\
\hline $41-50$ & $271(26.7)$ & $21(7.7)$ & $3.36(1.02-11.06)$ & $3.21(0.98-10.56)$ \\
\hline $51-60$ & $197(19.4)$ & $27(13.7)$ & $5.94(1.84-19.19)$ & $5.68(1.76-18.35)$ \\
\hline$\geq 61$ & $134(13.2)$ & $14(10.4)$ & $4.53(1.33-15.40)$ & $4.37(1.28-14.88)$ \\
\hline \multicolumn{5}{|l|}{ Schooling of study (years) } \\
\hline $0-4$ & $74(21.0)$ & $6(8.1)$ & 1 & \\
\hline $5-8$ & $139(39.5)$ & $12(8.6)$ & $1.06(0.42-2.73)$ & \\
\hline $9-11$ & $80(22.7)$ & $3(3.7)$ & $0.46(0.12-1.79)$ & \\
\hline$\geq 12$ & $59(16.8)$ & $1(1.7)$ & $0.21(0.03-1.69)$ & \\
\hline \multicolumn{5}{|l|}{ Home arrangement } \\
\hline Living alone & $224(29.2)$ & $25(11.2)$ & 1 & 1 \\
\hline Living with partner/friend & $208(27.2)$ & $19(9.1)$ & $0.82(0.46-1.44)$ & $1.35(0.66-2.75)$ \\
\hline Living with family members & $334(43.6)$ & $22(6.6)$ & $0.59(0.34-1.02)$ & $0.69(0.32-1.52)$ \\
\hline \multicolumn{5}{|l|}{ Smoking status } \\
\hline Yes & $530(66.8)$ & $61(11.5)$ & $2.03(1.17-3.50)$ & $1.12(0.50-2.49)$ \\
\hline No & $264(33.2)$ & $15(5.7)$ & 1 & 1 \\
\hline \multicolumn{5}{|l|}{ Alcohol use } \\
\hline Yes & $319(47.5)$ & $42(13.2)$ & $2.11(1.29-3.45)$ & $1.34(0.64-2.83)$ \\
\hline No & $352(52.5)$ & $22(6.3)$ & 1 & 1 \\
\hline \multicolumn{5}{|l|}{ Illicit drug use } \\
\hline Yes & 251(38.9) & $44(17.5)$ & $3.14(1.93-5.11)$ & $1.82(0.65-5.10)$ \\
\hline No & $394(61.1)$ & $22(5.6)$ & 1 & 1 \\
\hline \multicolumn{5}{|l|}{ Injectable drug use } \\
\hline Yes & $68(12.0)$ & $22(32.4)$ & $5.54(3.39-9.08)$ & $2.48(1.07-5.70)$ \\
\hline No & $497(87.8)$ & $29(5.8)$ & 1 & 1 \\
\hline \multicolumn{5}{|l|}{ Blood Transfusion } \\
\hline Yes & $36(12.9)$ & $4(11.1)$ & $1.17(0.43-3.20)$ & \\
\hline No & $243(87.1)$ & $23(9.5)$ & 1 & \\
\hline \multicolumn{5}{|l|}{ Heterosexual contact } \\
\hline Yes & $712(92.5)$ & $58(8.2)$ & $1.18(0.44-3.14)$ & \\
\hline No & $58(7.5)$ & $4(6.9)$ & 1 & \\
\hline \multicolumn{5}{|l|}{ Homosexual contact } \\
\hline Yes & $140(30.8)$ & $14(10)$ & $1.13(0.61-2.07)$ & \\
\hline No & $315(69.2)$ & $28(8.9)$ & 1 & \\
\hline \multicolumn{5}{|l|}{$\begin{array}{l}\text { Clinical characteristics: } \\
\text { Diabetes }\end{array}$} \\
\hline Yes & $71(7.0)$ & $11(15.5)$ & $2.01(1.12-3.61)$ & $1.73(0.83-3.59)$ \\
\hline No & $946(93.0)$ & $73(7.7)$ & 1 & 1 \\
\hline Dyslipidemia & & & & \\
\hline
\end{tabular}




\begin{tabular}{|c|c|c|c|c|}
\hline Yes & $119(11.7)$ & $8(6.7)$ & $0.79(0.39-1.60)$ & \\
\hline No & $898(88.3)$ & $76(8.5)$ & 1 & \\
\hline \multicolumn{5}{|l|}{ Hepatic Steatosis } \\
\hline Yes & $16(1.6)$ & $2(12.5)$ & $1.53(0.41-5.68)$ & \\
\hline No & $1001(98.4)$ & $82(8.2)$ & 1 & \\
\hline \multicolumn{5}{|l|}{ Hepatitis B } \\
\hline Yes & $28(2.7)$ & $7(25)$ & $3.21(1.63-6.32)$ & $6.36(3.23-12.54)$ \\
\hline No & $989(97.3)$ & $77(7.8)$ & 1 & 1 \\
\hline \multicolumn{5}{|l|}{ Obesity } \\
\hline Yes & $86(8.5)$ & $5(5.8)$ & $0.69(0.29-1.65)$ & \\
\hline No & $931(91.5)$ & $79(8.5)$ & 1 & \\
\hline \multicolumn{5}{|c|}{ First CD4 count (cells/mm³) } \\
\hline$\leq 200$ & $283(27.9)$ & $19(6.7)$ & 1 & \\
\hline $201-350$ & $167(16.5)$ & $18(10.8)$ & $1.61(0.87-2.97)$ & \\
\hline $351-500$ & $202(19.9)$ & $12(5.9)$ & $0.88(0.44-1.78)$ & \\
\hline$>500$ & $363(35.8)$ & $35(9.6)$ & $1.44(0.84-2.46)$ & \\
\hline \multicolumn{5}{|c|}{ Lowest CD4 count (cells/mm³) } \\
\hline$\leq 200$ & $398(39.2)$ & $29(7.3)$ & 1 & 1 \\
\hline $201-350$ & $266(26.2)$ & $26(9.8)$ & $1.34(0.81-2.23)$ & $1.56(0.81-3.00)$ \\
\hline $351-500$ & $181(17.8)$ & $9(5.0)$ & $0.68(0.33-1.41)$ & $1.26(0.56-2.83)$ \\
\hline$>500$ & $171(16.8)$ & $20(11.7)$ & $1.61(0.93-2.76)$ & $2.97(1.44-6.10)$ \\
\hline
\end{tabular}

$†$ Poisson Regression test adjusted for sex/gender, age, home arrangement, smoking status, alcohol user, illicit drugs user, injection drugs user, diabetes, hepatitis B and lowest CD4 count. Some variables are not included in the total sample due to missing data in the medical records. Source: Authors.

After adjusting the data for sex/gender, age, home arrangement, smoking status, alcohol use, illicit drug use, injectable drug use, diabetes, hepatitis B, and lowest CD4 count, the following variables remained statistically significant: sex/gender, injectable drug use and hepatitis B. Women living with HIV have $35 \%$ lower prevalence of HIV/HCV coinfection than men living with HIV; those who are injectable drug use (32.4\%) had a more than twice higher rate of HIV/HCV coinfections and those with hepatitis B (25\%) had a sixfold higher prevalence rate of HIV/HCV coinfection.

\section{Discussion}

The study evaluated the rate of HIV/HCV coinfection in people living with HIV/AIDS and treated at a referral service in southern Brazil, in which the sociodemographic, behavioral, and clinical factors were correlated with the observed prevalence. Coinfection was observed in $8.3 \%$ of the assessed population with a documented diagnosis, with most of them being male. This proportion was comparable to that observed in a cross-sectional study conducted in 249 HIV-infected adults at a Referral Hospital in northeast Ethiopia, where coinfection was found in 5.2\% of the patients (Gedefie et al., 2021).

At the adjusted analysis, the present study showed a significant association between the higher prevalence of HIV/HCV coinfection and injectable drug use (32.4\%). Similarly, Platt et al. (2016) showed a prevalence of HCV coinfection in people living with HIV of $6.2 \%$ and that $59 \%$ of injectable drug use had HIV/HCV coinfection. These authors showed that there was an association between injectable drug use and the prevalence of HIV/HCV coinfection (Platt et al., 2016). Previous studies have also reported an increased HIV/HCV coinfection rate in men and injectable drug use and found that the risky behavior is a significant factor in the increase in this coinfection rate (Mooran et al., 2018; Sahin et al., 2021).

According to the results, other studies also found a higher rate of HIV/HCV coinfection in injectable drug use and in individuals with hepatitis $\mathrm{B}(\mathrm{HBV})$. This finding is a frequent one, as these individuals share the same transmission routes (Baltazar et al., 2020; Chen et al., 2016; Raboni et al., 2014). In the adjusted analysis, a significant association of HIV/HCV coinfection was also observed in patients with hepatitis B $(25 \%)$.

A cross-sectional study of 399 patients in the city of Santiago, Chile, found that most (92.8\%) were male, 99.4\% acquired HIV through sexual contact (75.0\%); 25.7\% had AIDS and 90.4\% were receiving antiretroviral therapy (Weitzel et al., 2020). The authors observed that $6.5 \%$ had been vaccinated, $43.6 \%$ had resolved their HBV infection, and $5.8 \%$ were 
chronically infected. Coinfection with HCV was found in $1.0 \%$ of all patients (Weitzel et al., 2020). It differs from the present study regarding the proportion of cases and the evaluation of vaccination coverage.

From 2009 to 2013, Puglia et al. (2016) analyzed the notification of 1,354 new cases of HIV diagnoses in the Regional Surveillance System in Tuscany, Italy, in relation to the prevalence of HBV and HCV. Over a five-year period, 106 (7.8\%) people were reported as being coinfected with HIV/HCV, 56 (4.1\%) with HIV/HBV and 4 (0.3\%) with HIV/HCV/HBV. This study showed a similarity regarding the proportion of HIV/HCV coinfection and a lower proportion of $\mathrm{HIV} / \mathrm{HCV} / \mathrm{HBV}$ coinfection in relation to the observed results in the present study.

Variations in the HBV and HCV coinfection rates in people living with HIV/AIDS found in the assessed studies may be related to different geographic regions, risk groups and the type of exposure involved (Rockstroh, 2003; Tien, 2005). HBV and $\mathrm{HCV}$ coinfection in people living with HIV/AIDS is considered a major global public health problem, despite the availability of prevention and treatment strategies (Mattews et al., 2014). The management of these viral hepatitis in people living with HIV/AIDS is of great importance in morbidity and mortality prevention (Ryom et al., 2020), as these individuals are at high risk of mortality (Butt et al., 2020). Additionally, people living with HIV/HCV co-infection have an impaired quality of life both physically and mentally (Bonfim et al., 2021).

The main limitation of the present study may have been the collection of secondary data from medical records. Incomplete records and lack of clarity in the patients' records. The importance of improving the quality of the medical records is highlighted, so that all health professionals involved in the care of these patients have access to information, allowing a safe and continuous follow-up, contributing to decision-making.

\section{Conclusion}

In conclusion, the prevalence of $\mathrm{HIV} / \mathrm{HCV}$ coinfection was higher in male individuals, with injectable drug use and patients with hepatitis B. This supports the serological investigation of viral hepatitis in all people living with HIV/AIDS, especially in injectable drug use. It is important to understand the epidemiology and pathophysiology of HIV/AIDS coinfection with hepatotropic viruses, thus improving prevention, diagnosis, and treatment strategies. The diagnosis and effective management of viral hepatitis should be considered a priority for people living with HIV/AIDS, contributing to the reduction in mortality rates and quality of life improvement.

\section{References}

Baltazar, C. S., Boothe, M., Kellogg, T., Ricardo, P., Sathane, I., Fazito, E., Raymond, H. F., Temmerman, M., \& Luchters, S. (2020). Prevalence and risk factors associated with HIV/hepatitis B and HIV/hepatitis C coinfections among people who inject drugs in Mozambique. BMC Public Health, 20(1), 851. https://doi.org/10.1186/s12889-020-09012-w

Bonfim, R. O., Andrade, R. L. P., Reis, R. K., Ferreira, M. R. L., Orfão, N. H., Villa, T. C. S., \& Monroe, A. A. (2021). Quality of life of people with HIV/hepatitis C coinfection: a systematic review. Research, Society and Development, 10(10), e256101018162. http://dx.doi.org/10.33448/rsd-v10i10.18162

Brazil. Ministério da Saúde, Secretaria de vigilância em saúde, Departamento de DST/AIDS e Hepatites Virais. Boletim epidemiológico 2021. Available at www.aids.gov.br . Accessed in February 11th 2021.

Bruno, S., Di Marco, V., Iavarone, M., Roffi, L., Boccaccio, V., Crosignani, A., Cabibbo, G., Rossi, S., Calvaruso, V., Aghemo, A., Giacomelli, L., Craxì, A., Colombo, M., \& Maisonveuve, P. (2017). Improved survival of patients with hepatocellular carcinoma and compensated hepatitis C virus-related cirrhosis who attained sustained virological response. Liver International, 37(10), 1526-1534.

Butt, Z. A., Wong, S., Rossi, C., Binka, M., Wong, J., Yu, A., Darvishian, M., Alvarez, M., Chapinal, N., McKee, G., Gilbert, M., Tyndall, M. W., Krajden, M., \& Janjua, N. Z. (2020). Concurrent hepatitis C and B virus and human immunodeficiency virus infections are associated with higher mortality risk illustrating the impact of syndemics on health outcomes. Open Forum Infectious Disease, 7(9), ofaa347. https://doi.org/10.1093/ofid/ofaa347

Carvalho, C. I. M., Ferreira, V. S., \& Leitão, J. M. S. R. (2020). Perfil epidemiológico de pacientes com Hepatite C no componente especializado da assistência farmacêutica do Piauí. Research, Society and Development, 9(3), e06932265. http://dx.doi.org/10.33448/rsd-v9i3.2265

Chen, M., Wong, W. W., Law, M. G., Kiertiburanakul, S., Yunihastuti, E., Merati, T. P., Lim, P. L., Chaiwarith, R., Phanuphak, P., Lee, M. P., Kumarasamy, N., Saphonn, V., Ditangco, R., Sim, B. L. H., Nguyen, K. V., Pujari, S., Kamarulzaman, A., Zhang, F., Pham, T. T., Choi, J. Y., Oka, S., Kantipong, P., 
Mustafa, M., Ratanasuwan, W., Durier, N., \& Chen, Y. M. A. (2016). Hepatitis B and C Co-Infection in HIV Patients from the TREAT Asia HIV Observational Database: Analysis of Risk Factors and Survival. PLoS One, 11(3), e0150512. https://doi.org/10.1371/journal.pone.0150512

Focà, E., Fabbiani, M., Prosperi, M., Roldan, E. Q., Castelli, F., Maggiolo, F., Di Filippo, E., Di Giambeneetto, S., Gagliardini, R., Saracino, A., Di Pietro, M., Gori, A., Sighinolfi, L., Pan, A., Postorino, M. C., Torti, C., \& Italian Master Cohort. (2016). Liver fibrosis progression and clinical outcomes are intertwined: role of CD4+ T-cell count and NRTI exposure from a large cohort of HIV/HCV-coinfected patients with detectable HCV-RNA: A MASTER cohort study. Medicine (Baltimore), 95(29), e4091. https://doi.org/10.1097/MD.0000000000004091

Gallo, R. C. \& Montagnier, L. (2003). The discovery of HIV as the cause of AIDS. The New England Journal of Medicine, 349, $2283-2285$.

Gedefie, A., Adamu, A., Alemayehu, E., Kassa, Y., Belete, M. A. (2021). Hepatitis C Virus Infection among HIV-Infected Patients Attending Dessie Referral Hospital, Northeastern Ethiopia. International Journal of Microbiology, 2021, 6675851. https://doi.org/10.1155/2021/6675851

Le Loup, G., de Assis, A., Costa-Couto, M. H., Thoenig, J.-C., Fleury, S., de Camargo, K., \& Larouzé, B. (2009). A public policy approach to local models of HIV/AIDS control in Brazil. American Journal of Public Health, 99(6), 1108-1115.

Matthews, P. C., Geretti, A. M., Goulder, P. J., \& Klenerman, P. (2014). Epidemiology and impact of HIV coinfection with hepatitis B and hepatitis C viruses in Sub-Saharan Africa. Journal of Clinical Virology, 61(1), 20-33.

Mirzaei, M., Poorolajal, J., Khazaei, S., \& Saatchi, M. (2013). Survival rate of AIDS disease and mortality in HIV-infected patients in Hamadan, Iran: a registry-based retrospective cohort study (1997-2011). International Journal of STD \& AIDS, 24(11), 859-866.

Moorman, J. P., Krolikowski, M. R., Mathis, S. M., \& Pack, R. P. (2018). HIV/HCV Co-infection: Burden of Disease and Care Strategies in Appalachia. Current HIV/AIDS Reports, 15(4), 308-314.

Mugisha, J. O., Schatz, E. J., Randell, M., Kuteesa, M., Kowal, P., Negin, J., \& Seeley, J. (2016). Chronic disease, risk factors and disability in adults aged 50 and above living with and without HIV: findings from the Wellbeing of Older People Study in Uganda. Global Health Action, 9, 31098. https://doi.org/10.3402/gha.v9.31098

Palella, F. J., Jr., \& Phair, J. P. (2011). Cardiovascular disease in HIV infection. Current Opinion in HIV and AIDS, 6(4), $266-271$.

Pereira A. S., Shitsuka, D. M., Parreira, F. J. \& Sitsuka, R. (2018). Metodologia da pesquisa científica. UFSM.

Peters, L., Laut, K., Resnati, C., Del Campo, S., Leen, C., Falconer, K., Trofimova, T., Paduta, D., Gatell, J., Rauch, A., Lacombe, K., Domingo, P., Chkhartishvili, N., Zangerie, R., Matulionyte, R., Mitsura, V., Benfield, T., Zilmer, K., Khromova, I., Lundgren, J., Rockstroh, J., Mocroft, A., \& EuroSIDA Study Group. (2018). Uptake of hepatitis C virus treatment in HIV/hepatitis C virus-coinfected patients across Europe in the era of direct-acting antivirals. AIDS, 32(14), 1995-2004.

Platt, L., Easterbrook, P., Gower, E., McDonald, B., Sabin, K., McGowan, C., Yanny, I., Razavi, H., \& Vickerman, P. (2016). Prevalence and burden of HCV co-infection in people living with HIV: a global systematic review and meta-analysis. The Lancet Infectious Diseases, 16(7), 797-808.

Puglia, M., Stasi, C., Da Frè, M., \& Voller, F. (2016). Prevalence and characteristics of HIV/HBV and HIV/HCV coinfections in Tuscany. Brazilian Journal of Infectious Disease, 20, 330-334.

Raboni, S. M., Tuon, F. F., Beloto, N. C., Demeneck, H., Oliveira, A., Largura, D., Sagrado, A. G., Lima, B. P., Franzoni, J. P., \& Pedroso, M. L. (2014). Human immunodeficiency virus and hepatitis C virus/hepatitis B virus co-infection in Southern Brazil: clinical and epidemiological evaluation. Brazilian Journal of Infectious Disease, 18(6), 664-668.

Rallón, N., García, M., García-Samaniego, J., Rodríguez, N., Cabello, A., Restrepo, C., Álvarez, B., García, R., Górgolas, M., \& Benito, J. M. (2017). HCV coinfection contributes to HIV pathogenesis by increasing immune exhaustion in CD8 T-cells. PLoS One, 12(3), 0173943. https://doi.org/10.1371/journal.pone.0173943

Rockstroh, J. K. (2003). Management of hepatitis B and C in HIV co-infected patients. Journal of Acquired Immune Deficiency Syndrome, 34(Suppl 1), 5965 .

Rosenthal, E., Roussillon, C., Salmon-Céron, D., Georget, A., Hénard, S., Huleux, T., Gueit, I., Mortier, E., Costagliola, D., Morlat, P., Chêne, G., Cacoub, P., Mortalité 2010, \& Germivic Study Groups. (2015). Liver-related deaths in HIV-infected patients between 1995 and 2010 in France: the Mortavic 2010 study in collaboration with the Agence Nationale de Recherche sur le SIDA (ANRS) EN 20 Mortalité 2010 survey. HIV Medicine,16(4), $230-239$.

Ryom, L., Cotter, A., de Miguel, L., Béguelin, C., Podlekareva, D., Arribas, J. R., Marzolini, C., Mallon, P. G. M., Rauch, A., Kirk, O., Molina, J. M., Guaraldi, G., Winston, A., Bhagani, S., Cinque, P., Kowalska, J. D., Collins, S., \& Battegay, M. (2020). 2019 update of the European AIDS Clinical Society Guidelines for treatment of people living with HIV version 10.0. HIV Medicine, 21(10), 617-624.

Şahin, M., Aydın, Ö. A., Karaosmanoğlu, H. K., \& Yıldırım, M. (2021). Seroprevalence of HBsAg and Anti-HCV among HIV Positive Patients. Viral Hepatitis Journal, 27(1), 24-30.

Silva, C. M., Peder, L. D., Silva, E. S., Previdelli, I., Pereira, O. C. N., Teixeira, J. J. V., \& Bertolini, D. A. (2018). Impact of HBV and HCV coinfection on CD4 cells among HIV-infected patients: a longitudinal retrospective study. Journal of Infection in Developing Countries, 12(11), $1009-1018$.

Tengan, F. M., Ibrahim, K. Y., Dantas, B. P., Manchiero, C., Magri, M. C., \& Bernardo, W. M. (2016). Seroprevalence of hepatitis C virus among people living with HIV/AIDS in Latin America and the Caribbean: a systematic review. BMC Infectious Diseases, 16, 663. https://doi.org/10.1186/s12879-016-1988y

Tien, P. C. (2005). Management and treatment of hepatitis C virus infection in HIV-infected adults: recommendations from the Veterans Affairs Hepatitis C Resource Center Program and National Hepatitis C Program Office. American Journal of Gastroenterology, 100(10), $2338-2354$. 
Research, Society and Development, v. 11, n. 3, e22611326405, 2022

(CC BY 4.0) | ISSN 2525-3409 | DOI: http://dx.doi.org/10.33448/rsd-v11i3.26405

UNAIDS - Joint United Nations Programmer on HIV/AIDS (UNAIDS) and World Health Organization (WHO). Report on the global AIDS epidemic 2021. Available at https://www.unaids.org/sites/default/files/media_asset/2021-global-aids-update_en.pdf.

Weitzel, T., Rodríguez, F., Noriega, L. M., Marcotti, A., Duran, L., Palavecino, C., Porte, L., Aguilera, X., Wolff, M., \& Cortes, C. P. (2020). Hepatitis B and $\mathrm{C}$ virus infection among HIV patients within the public and private healthcare systems in Chile: A cross-sectional serosurvey. PLoS One, 15(1), e0227776. https://doi.org/10.1371/journal.pone.0227776

WHO - World Health Organization. Global health sector strategy on viral hepatitis 2016-2021. Towards ending viral hepatitis. World Health Organization; 2016. https://apps.who.int/iris/handle/10665/246177.

Zayedi, E., Makvandi, M., Teimoori, A., Samarbaf-Zadeh, A. R., Chafari, S., Seyedian, S. S., \& Azaran, A. (2020). Prevalence of hepatitis C virus among HIV-infected patients. Iranian Journal of Microbiology, 12(2), 156-163.

Zheng, Y. X., Ma, S. J., Xiong, Y. H., Fan, X. G. (2020). Efficacy and safety of direct acting antiviral regimens for hepatitis C virus and human immunodeficiency virus co-infection: systematic review and network meta-analysis. Journal of Gastroenterology and Hepatology, 35(9), $1477-1487$. 